\title{
Materials for biota of lichens and lichenicolous fungi in the military area near Toruń, Poland
}

\author{
Edyta Adamska, Milosz Deptuła \\ Nicolaus Copernicus University, Faculty of Biology and Environment Protection, \\ Chair of Geobotany and Landscape Planning, \\ Lwowska 1, 87-100 Torun, Poland, \\ e-mail: adamska@umk.pl
}

\begin{abstract}
The paper presents the first species list of lichens and lichenicolous fungi found and identified in the artillery training area located near the city of Torun. Lichenological studies were conducted in that area in 1998-2001 and 2009. A total of 100 taxa were identified, including 4 species of lichenicolous fungi, with particular emphasis on epigeic lichens - mainly from the genus Cladonia and Cetraria associated with heaths and arenaceous grasslands. The identified lichens include some threatened and protected taxa, i.a. Bryoria subcana, Cetraria islandica, Physconia distorta, Peltigera canina, P. polydactylon, P. praetextata, Ramalina fraxinea, Stereocaulon condensatum.
\end{abstract}

Key words: military area, psammophilous grasslands, heathland, lichen biota, threat, protection.

\section{Introduction}

There are 7 large military training grounds in Poland, with a total area of 90,000 ha. The training ground in Torun is one of the oldest and the largest facilities of this type, not only in Poland but also in Europe (Wasilewski, 2004). Since the mid-17th century, area IV of the dune field located in the Torun Basin was used as an artillery range. The military activity in this area, involving cutting of trees and shrubs, military trainings and frequent fires, has contributed to the preservation of non-forest habitats. The artillery range near Torun is covered in $99.4 \%$ with forests of varying age and heaths (Gugnacka-Fiedor \& Adamska, 2010).

Floristic studies were carried out in this area already in the 19th century and in the early 20th century (Scholz, 1896; Abromeit et al., 1898; Preuss, 1912). After a long break, floristic studies were resumed (Wilkoń-Michalska, 1971; Chojnacka et al., 2010a; 2010b; Gugnacka-Fiedor \& Adamska, 2010).
Although areas used by the army are interesting in terms of nature, the literature on their lichen biota is still scanty because of the difficult access (e.g.: Ciaciura et al., 2013; Dingová \& Pišút, 2010; Motiejūnaitè, 1996, 2007; Gilbert, 2000).

Due to the presence of habitats such as grasslands and heaths, the artillery range near Torun represents a valuable lichenological area. The area is particularly rich in epigeic, epiphytic and epilithic lichens, including threatened and protected species. Some data on the lichens of the military training ground were published by Gugnacka-Fiedor and Adamska (2010), Chojnacka et al. (2010a, 2010b) and Ceynowa-Giełdon et al. (2004).

The objective of this study is to present the list and the distribution of lichen species as well as lichenicolous fungi identified on the military training ground near Torun. 


\section{Location}

In the Torun Basin, dunes are the dominant component of the land relief (Kondracki, 2001). The study area is located on one of the six dune fields, referred to as Torun-Aleksandrów-Gniewkowo dune fields (Mrózek, 1958). The field is one of the largest dune fields in the Torun Basin. It covers an area of ca. $223 \mathrm{~km}^{2}$. The dominant land form are parabolic dunes formed at the end of the last glaciation and characteristic of extensive sandy terraces occurring along large rivers. In the Holocene (Klimaszewski, 1978; Noryśkiewicz, 2013), these areas were covered with pine forests and only the human activity in the last millennium, especially deforestation, induced aeolian processes. Infertile podzolic soils with acid reaction and a small content of humus dominate in the area (Burak \& Jankowski, 1991).

From the 17th century, part of the dune has been continuously used as an artillery range. The area is owned by the State Treasury and used by the Artillery and Armaments Training Centre in Torun. It is located in the commune of Wielka Nieszawka (Fig. 1). The military training ground is largely overgrown with pine wood which remains under the administration of Gniewkowo Forest Division. The training ground covers an area of ca. 12,000 ha (Wasielewski, 2004) and its northern boundary coincides with the southern city limit of Torun'; the western boundary runs along the line: Torun - Podgórz, the Forest District of Glinki, the railway line Torun - Inowrocław to Suchatów$\mathrm{ka}$; the southern limit runs along the villages: Suchatówka, Kijewo, Grabie, the Tążyna River and the Pieczenia Forest Division and villages: Otłoczyn and Odolin; the eastern limit runs along a bridge above the Tążyna River, road no. 1 and the line of villages: Brzoza, Czerniewice and Torun - Stawki. Dorożyński (2001) described these limits as: E $018^{\circ} 29^{\prime}-018^{\circ} 44^{\prime}$ and $\mathrm{N} 052^{\circ} 51^{\prime}-052^{\circ} 59^{\prime}$

The area is covered by a network of roads, both hardened (concrete, paved and asphalted) and not hardened. Firebreaks, ditches and anti-tank barriers are located in the area, as well as engineering and technical buildings in the form of trenches and shelters. Remains of a prisoner-of-war camp from World War II are located in the northern part of the training ground (Wasilewski, 2004).

According to the current nature and forest regionalization (Trampler, 1990), the studied area is located in the

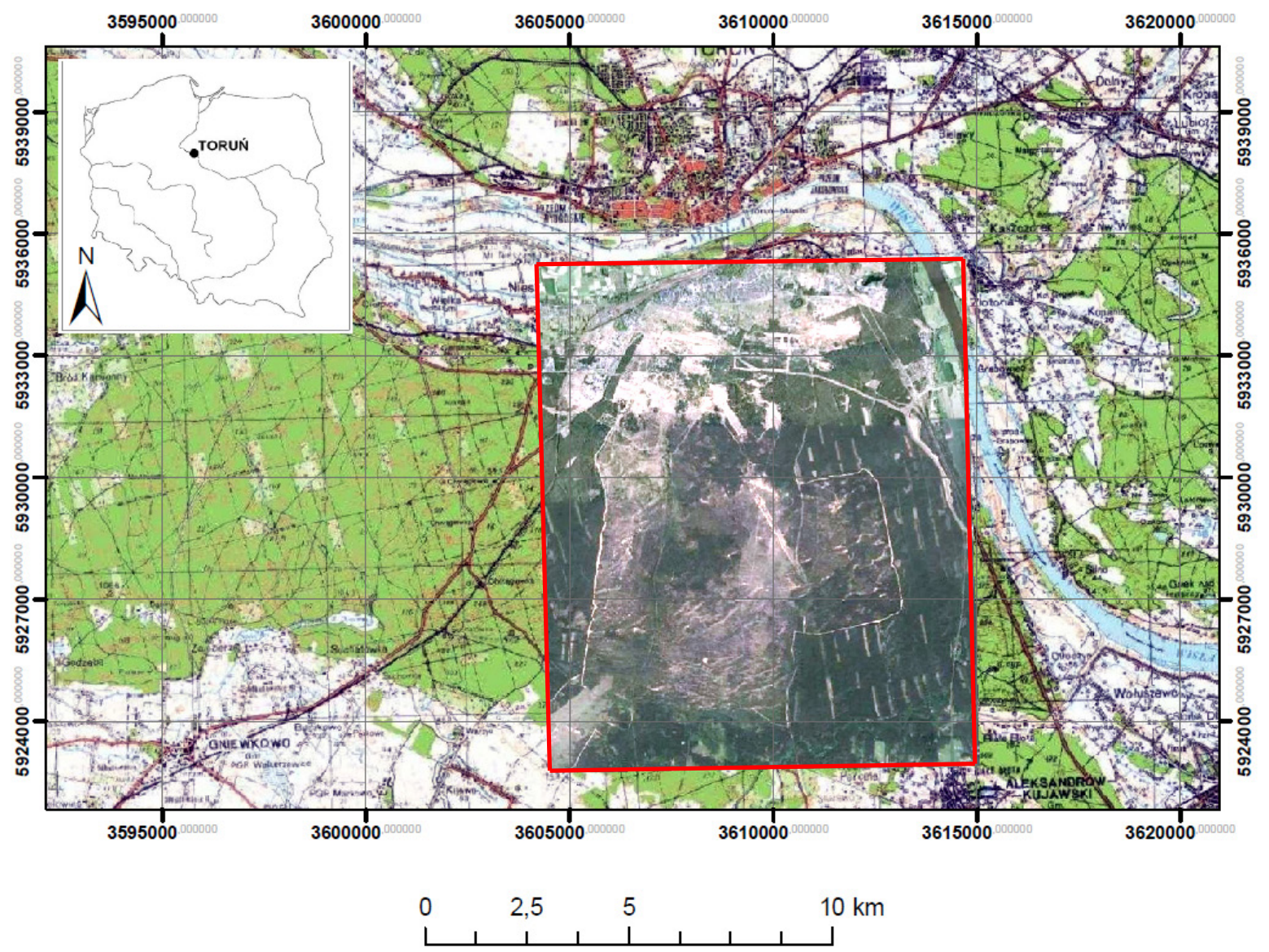

Figure 1. Location of the study area (red line) 
Wielkopolska-Pomerania Region (III); the region of the Torun-Płock Basin (5), the mesoregion of the Toruń-Płock Basin (5.a), the region of Wielkopolska-Pomerania Lowlands (7.) and the Mesoregion of the Wielkopolska Lake District (7.b).

According to the division of the country into physical and geographical mesoregions (Kondracki, 2001), the area is located in the Mesoregion of Non-Alpine Central Europe, the Province of the Central-European Lowland, the Subprovince of the South Baltic Lake District, the Macroregion of the Torun-Eberswald Ice-Marginal Valley (1), the mesoregion of the Torun Basin, the Macroregion of the Wielkopolska Lake District (2), the mesoregion of the Inowrocław Plain.

According to the division of Poland into geobotanical regions by Szafer and Pawłowski (1972), the forest division is located in the following units of the geobotanical division: the Baltic Divide, the Subdivide of the Great Valleys; the Region of Wielkopolska and Kujawy; the Kuyavian District.

In accordance with the regulation of the Torun Provincial Governor as of the 10th of December 1992, the military training ground was granted the status of the protected landscape referred to as "the Dune area to the south of Toruń" (Burak, 2001).

\section{Methods}

Lichenological studies were carried out in 1998-2001 and 2009 by E. Adamska at 33 sites (Fig. 2) in the artillery training area near Torun.

Some of the species were identified in the field, while specimens of others were deposited at the Herbarium of the Department of Geobotany and Landscape Planning, Nicolaus Copernicus University in Torun (TRN). Data on the occurrence of lichens were collected from all available substrates: bark of trees - in particular roadside trees, twigs of Calluna vulgaris, wood, sandy soil and concrete constructions - bunkers, shelters, concrete rubble. Protected species were not collected. Due to the limited access to the training ground and, consequently, time restrictions on each stay in the study area, more detailed fieldwork was not possible.

The collected specimens of lichens were identified using the standard lichenological methods, based mainly on the paper by Smith et al. (2009) as well as several identification keys and monographs. The names of taxa were accepted mainly after Diederich et al. (2015), Czyżewska \& Kukwa (2009), except for taxa from the genera Teloschistaceae Zahlbr. (ARUP et al. 2013), Verrucaria Schrad. (Krzewicka, 2012), the group of Lecanora dispersa (Śliwa, 2007) and the species: Cladonia arbuscula s.l. (Piercey-Normore et al. 2010), C. floerkeana and C. uncialis (Santesson et al. 2004) and L. saxicola (Laundon, 2010).

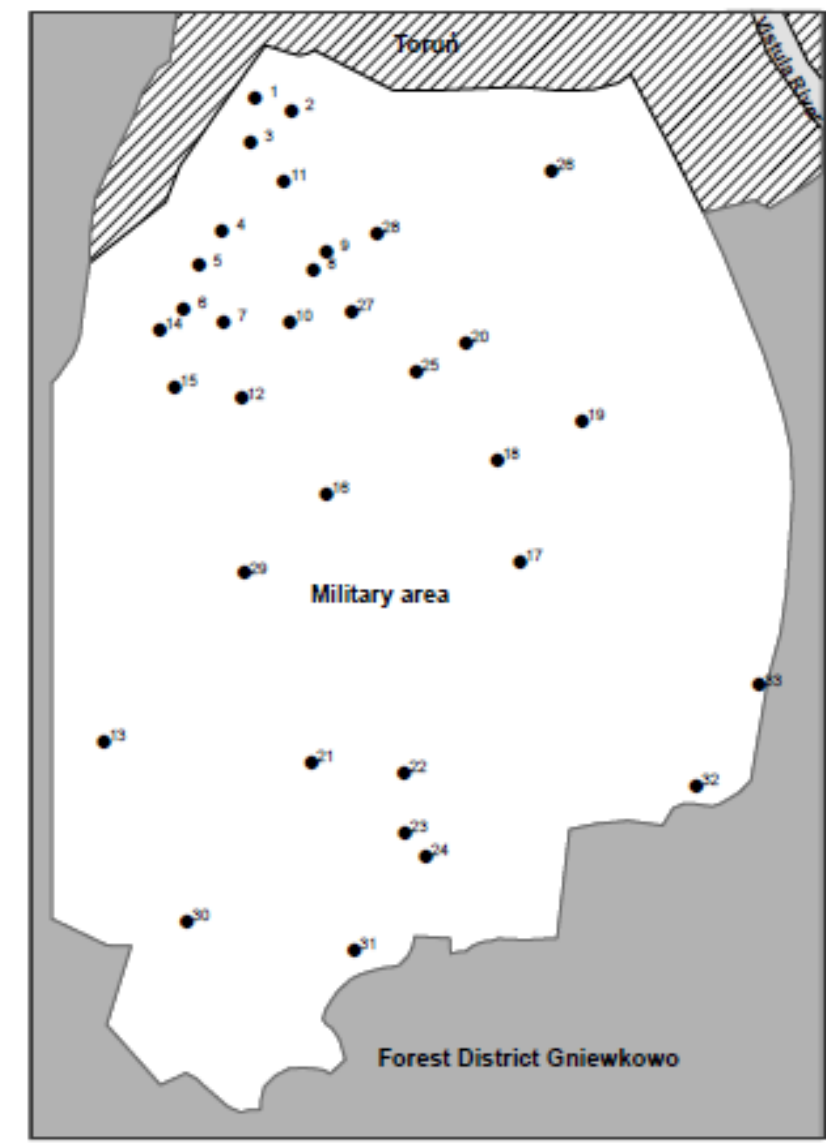

Figure 2. Location of the 1-33 localities (black dots) on the military area

Specimens from the genus Lepraria not subjected to TLC (Orange et al. 2001) were defined as Lepraria sp. and Cladonia from the group of chlorophaea - as Cladonia chlorophaea s.1. Threat categories of lichens in Poland were quoted after Cieśliński et al. (2006). The conservation status of lichen species was collated in accordance with the Regulation of the Minister of the Environment (2014).

Taxa were listed in alphabetic order. The list contains information on lichens' substrates and the list of sites at which a given taxon was found.

\section{List of localities}

1 - bifurcation concrete roads; 52 $59^{\prime} 20^{\prime \prime} \mathrm{N}, 18^{\circ} 35^{\prime} 30^{\prime \prime} \mathrm{E}$; 2 - trench - South, concrete foundations; 52 $59^{\prime} 00^{\prime \prime} \mathrm{N}$, 18 35'10”'E; 3 - crossroads; 52 $58^{\prime} 50^{\prime \prime} \mathrm{N}, 18^{\circ} 35^{\prime} 00^{\prime \prime} \mathrm{E}$; 4 - Droga Popiołowa - east; 52॰58'05’N, 18³4’30”'E; 5 - Droga Popiołowa - crossroads; 52 $57^{\prime} 50^{\prime \prime} \mathrm{N}$, 18³4'20”E; 6 - Góra Żymierskiego; 5257’40”N 
18³4'05”E; 7 - shelter; 52॰59'00”N, 18॰35'10”E; 8-road S, Góra Krzyżowa; 52॰57’40’”N, 18³5’40”E; 9 - road S, Góra Krzyżowa; 52॰57'50”N, 18³5'50”E; 10 - Droga Wudecka, dry lake; 52॰57’30’N, 18³5'30’"E; 11 - Góra Sypka - E; 52 58'30”N, 18³5'20’'E; 12 - Góra Partyzantów, Góra Bodnara; 52 $2^{\circ} 7^{\prime} 00^{\prime} \mathrm{N}, 18^{\circ} 35^{\prime} 00^{\prime} \mathrm{E}$; 13 - field of fire Kijewo - N; 5254'10’N, 18³5'20”E; 14 - Góra Żymierskiego - N, bunker and the ruins of buildings; $52^{\circ} 57^{\prime} 20^{\prime \prime} \mathrm{N}, 18^{\circ} 34^{\prime} 05^{\prime}$ 'E; 15 - Góra Krzywoustego - slope S; 52 $56^{\prime} 50^{\prime \prime} \mathrm{N}, 18^{\circ} 34^{\prime} 20^{\prime \prime} \mathrm{E}$; 16 - Góra Orla; 52 $56^{\prime} 00^{\prime} \mathrm{N}$

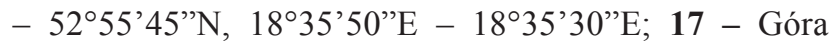
Taras - slope S; 52 $55^{\prime} 50^{\prime \prime} \mathrm{N}, 18^{\circ} 38^{\prime} 20^{\prime \prime} \mathrm{E}$; 18 - Góra Ze-

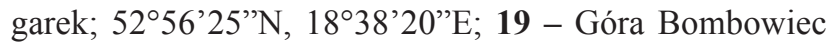
- slope S; 52 $56^{\prime} 40^{\prime \prime} \mathrm{N}, 18^{\circ} 39^{\prime} 20^{\prime \prime} \mathrm{E} ; 20$ - by the roadside Warszawska; 52 $57^{\prime} 15^{\prime \prime} \mathrm{N}, 18^{\circ} 37^{\prime} 45^{\prime \prime} \mathrm{E} ; 21$ - Góra Rezerwat; 52 $54^{\prime} 05^{\prime}$ N, $18^{\circ} 36^{\prime} 05^{\prime} \mathrm{E}$; 22 - Góra Pieczenia; $52^{\circ} 54^{\prime} 05^{\prime} \mathrm{N}, 18^{\circ} 37^{\prime} 10^{\prime \prime} \mathrm{E}$; 23 - Góra Pieczenia in the direction of the road Służewska; 52 53'35'N, $18^{\circ} 37^{\prime} 15^{\prime \prime} \mathrm{E}$; 24 - by the roadside Służewskiej; 52 53'25'N, 18³7'25'E; 25 - Góra Czarniecki, Góra Ucho, Góra Warszawska

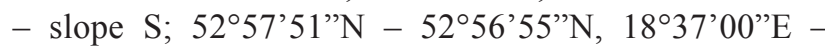


27 - Góra Dziwak; 5257’20”N, 18³6’40”E; 28 - Góra Wiesława; 52 $58^{\prime} 10^{\prime \prime} \mathrm{N}, 18^{\circ} 36^{\prime} 30^{\prime \prime} \mathrm{E} ; 29$ - Droga Wudecka - barrier; $52^{\circ} 55^{\prime} 30^{\prime \prime} \mathrm{N}, 1^{\circ} 35^{\prime} 10^{\prime \prime} \mathrm{E} ; 30$ - Stare Grabie - gravel pit; $52^{\circ} 55^{\prime} 30^{\prime} \mathrm{N}, 18^{\circ} 35^{\prime} 00^{\prime \prime} \mathrm{E} ; 31$ - Maciejewo; 52 52'40”N, 18³6’40”'E; 32 - Road to Otłoczyn; $52^{\circ} 55^{\prime} 00^{\prime} \mathrm{N}, 18^{\circ} 41^{\prime} 50^{\prime \prime} \mathrm{E} ; 33$ - Otłoczyn railway station; $52^{\circ} 55^{\prime} 00^{\prime \prime} \mathrm{N}, 18^{\circ} 41^{\prime} 50^{\prime \prime} \mathrm{E}$.

\section{Results and discussion}

A total of 96 lichen taxa and 4 species of lichenicolous fungi were identified in the artillery range near the city of Torun. The list of lichen species includes taxa, the identification of which is certain: Cladonia $\mathrm{cf}$. pyxidata subsp. pocillum, Peltigera cf. polydactylon and taxa identified to the genus level: Lepraria sp. Furthermore, e.g. specimens of Candelaria concolor (Dick.) Stein s.l. were not collected, so there is no certainty that they included recently described specimens of C. pacifica M. Westb. \& Arup (Westberg \& Arup, 2011). No subspecies were distinguished within the species Cladonia uncialis (subsp. uncialis and biuncialis), because the species was not collected from all sites.

For comparison, Gilbert (2000) reported the occurrence of ca. 150 taxa of lichens during lichenological studies conducted in military areas of Great Britain. His paper, however, dealt mainly with epilithic species growing on a military airport apron. The author reports also epigeic species found on spreads of gritty soil, including species from the genus Cladonia, but also Colllema tenax, Leptogium gelatinosum and Catapyrenium sguamulosum (cf. Ceynowa-Giełdon et al., 2004). Cladonia furcata and C. rangi- formis (Gilbert, 2000) occurred in large numbers near the edge of the airport apron.

During mycological and lichenological investigations in 7 former Soviet military forest divisions, Motiejūnaite (1996) identified over two times more taxa than reported from the military training ground near Torun - 204 species of lichenized, lichenicolous and resinicolous fungi. Similarly to the training ground near Toruń, Motiejūnaitè's list included epigeic taxa, as well as taxa growing on the wood, bark of trees and rock substrates.

When conducting lichenological studies in Žemaitija National Park (Lithuania), the author reported 273 taxa, including 113 taxa from the military areas (Motiejūnaitè, 2007).

Dingová \& Pišút (2010) report sites of Cladonia glauca found in the military area Kotlina (SW Slovakia) on sandy soil.

Out of the total number of species found on the military training ground near Torun, 16 species are on the Red List of threatened lichens in Poland (Cieśliński et al., 2006) (Table 1), including: 1 Criticaly Endangered (CR) - B. subcana; 3 Endangered (EN) - Physconia distorta, Ramalina fraxinea, Tuckermanopsis sepincola; 9 Vulnerable (VU) Bryoria fuscescens, Cetraria islandica, Peltigera canina, P. polydactylon, P. praetextata, Ramalina farinacea, Stereocaulon condensatum, Tuckermanopsis chlorophylla, $U$. hirta; 2 Near Threatened (NT) - Evernia prunastri, Hypogymnia tubulosa and 1 species Least Concern (LC) Phaeophyscia sciastra.

Consistent with the Regulation of the Minister of the Environment on the wild species of fungi in Poland from 2014 (Regulation, 2014), 17 taxa are protected (Table 2), including 4 strictly protected taxa: Bryoria subcana, Peltigera praetextata, Ramalina fraxinea, Tuckermanopsis sepincola and 13 partially protected: Bryoria fuscescens, Cetraria islandica, Cladonia arbuscula, C. ciliata, C. portentosa, C. rangiferina, Hypogymnia tubulosa, Peltigera canina, P. polydactylon, Ramalina farinacea, Stereocaulon condensatum, Tuckermanopsis chlorophylla, Usnea hirta.

For comparison, out of 66 lichen species identified in the area of the planned nature reserve "Diabelskie Pustacie" used by the army (Ciaciura et al., 2006) and located in the commune of Borne Sulinowo, nine species are on the list of threatened lichens in Poland, i.e.: Bryoria subcana, Pycnothelia papillaria, Usnea hirta, U. subfloridana, Tucermannopsis chlorophylla, Cetraria islandica, Peltigera canina, Hypogymnia tubulosa and Vulpicida pinastri.

A total of 36 epigeic lichen species were found on the military training ground near Toruń, as well as 34 taxa of epiphytes, 19 species of lichens on concrete constructions (walls of shelters and bunkers) and 13 species on the wood. Twenty five species of epigeic lichens occurred on heaths, including abundant occurrence of species from the genus Cladonia. Stereocaulon condensatum occurred 
in large numbers with well-developed thalli and apothecia. Whereas Ciaciura et al. (2006) reported 32 epigeic species (nearly half of the lichen taxa identified in the study area), including mostly taxa from the genus Cladonia. Those taxa, similarly to taxa from the Torun training ground, occurred in large numbers in deforested areas, on heaths, and contrary to Torun - also in open pine forests and occasionally on peat bogs.

A total of 33 epiphytic lichens were found in the area of the planned nature reserve "Diabelskie Pustacie"; they occurred in pine forests encroaching on heathlands and peat bogs (Ciaciura et al., 2006). Epiphytic lichens from the training ground near Torun occurred on the bark of roadside trees.

Corniculario-Corynephoretum is one of the most common associations identified on the military training ground in Toruń, dominated by e.g. Cetraria aculeata, Cladonia foliacea, Cladonia macilenta and C. verticillata. A total of 30 lichen species were identified in the association Arctostaphylo-Callunetum - the species-richest association occurring in the central part of the Torun training ground, on dune slopes and flat areas. Taxa from the genus Cladonia dominate, including mainly: Cladonia arbuscula s.1., C. cervicornis, C.coccifera, C. cornuta, C. deformis, C. furcata, C. gracilis, C. macilenta, $C$. portentosa, as well as C. subulata and Stereocaulon condensatum. Cladonia cariosa, C. cenotea, Baeomyces rufus and Trapeliopsis granulosa (cf. Gugnacka-Fiedor \& Adamska, 2010) occur less frequently. A similar species composition is reported by Adamska (2010) from Zadroże Dune located in the vicinity of the military ground and from the area of Torun city (Adamska, 2013, 2014).

Scientific research and protection measures aimed at preservation of valuable habitats are largely hampered in areas used by the army. Krenz et al. (2013) describe the impact of the military use on the preservation of dry heaths based on the example of SAC Colbitz-Letzlinger Heide in Germany.

Also Ciaciura et al. (2006) emphasize the necessity of implementing the active protection which prevents the secondary succession in phytocoenoses of heaths and grasslands.

The following abbreviations are used: * - names of lichenicolous fungi, on the bark of: Bp - Betula pendula, $\mathrm{Cv}$ - Calluna vulgaris, Fe - Fraxinus excelsior, Ps - Pinus sylvestris, Po - Populus ssp., Pt - Populus tremula, Rp - Robinia pseudoacacia, Qr - Quercus robur, So - Salix ssp.; 1-33 - number of localities.

\section{List of species}

1. Athallia holocarpa (Hoffm.) Arup, Frödén \& Søchting [Caloplaca holocarpa (Hoffm.) A. E. Wade] - on concrete; 7, 10, 14.

2. *Athelia arachnoidea (Berk.) Jülich - on Lecanora conizaeoides; 6, 8, 9, 11, 19, 21, 25, 26, 32.

3. Baeomyces rufus (Huds.) Rebent. - on soil, on psammophilous grasslands and heathlands; 17.

4. Bryoria fuscescens (Gyeln.) Brodo \& D. Hawksw. Bp, on wood; 6, 17, 29.

5. Bryoria subcana (Stizenb.) Brodo \& D. Hawksw. - on wood; 30.

6. Buellia griseovirens (Sm.) Almb. - Bp, Qr, on wood; $17,29$.

7. Buellia punctata (Hoffm.) A. Massal. - Bp, Pt; 17, 29, 31.

8. Calogaya decipiens (Arnold) Arup, Frödén \& Søchting [Caloplaca decipiens (Arnold) Blomb. \& Forss.] - on concrete; 7.

9. Calogaya pusilla (A. Massal.) Arup, Frödén \& Søchting [Caloplaca pusilla (A. Massal.) Zahlbr.] - on concrete; 7 .

10. Candelaria concolor (Dickson) B. Stein s.1. - Rp; 30.

11. Candelariella aurella (Hoffm.) Zahlbr. - on concrete; 7, 10,14

12. Cetraria aculeata (Schreb.) Fr. - on soil, on psammophilous grasslands; 1-6, 8, 11, 17-19, 25-28, 30.

13. Cetraria islandica (L.) Ach. - on soil, on psammophilous grasslands and heathlands; 1, 3, 4, 8, 11, 19, 26, 28.

14. Circinaria calcarea (L.) A. Nordin, S. Savić \& Tibell - on concrete; 14.

15. Cladonia arbuscula (Wallr.) Flot. subsp. beringiana Ahti [C. arbuscula subsp. squarrosa (Wallr.) Ruoss] on soil, on heathlands; 2, 4, 8, 17, 19, 25, 26, 28.

16. Cladonia arbuscula subsp. mitis (Sandst.) Ruoss - on soil, on heathlands; 1-3, 6, 8, 11, 14-21, 25-28.

17. Cladonia cariosa (Ach.) Spreng. - on soil, on psammophilous grasslands and heathlands; 6 .

18. Cladonia cenotea (Ach.) Schaer. - on soil, on psammophilous grasslands and heathlands; 19.

19. Cladonia cervicornis (Ach.) Flot. - on soil, on psammophilous grasslands and heathlands; 1-4, 6, 10-12, 14, 18-20, 26.

20. Cladonia chlorophaea (Sommerf.) Spreng. s.1. - on soil, on heathlands; 2, 10, 11, 13-16, 26, 28.

21. Cladonia ciliata Stirt. - on soil; 26.

22. Cladonia coccifera (L.) Willd. - on soil, on psammophilous grasslands and heathlands; 4, 5, 14, 16, 17, 20, 21.

23. Cladonia coniocraea (Flörke) Spreng. - Bp, Ps, on wood; 2, 4, 11, 13, 14, 28, 29. 
24. Cladonia cornuta (L.) Hoffm. - on soil, on psammophilous grasslands and heathlands; 1-6, 8, 10, 15-17, 19-22, 26, 28-30, 32.

25. Cladonia crispata (Ach.) Flot. - on soil, on psammophilous grasslands and heathlands; 4.

26. Cladonia deformis (L.) Hoffm. - on soil, on heathlands; 1, 6, 13, 17, 21, 27.

27. Cladonia digitata (L.) Hoffm. - Bp, Ps, on wood; 2, 11, 14, 29.

28. Cladonia fimbriata (L.) Fr. - on soil, on psammophilous grasslands and heathlands; 1, 2, 4, 10, 11, 14, 16, 20, 26, 30 .

29. Cladonia floerkeana (Fr.) Flörke [C. macilenta subsp. floerkeana (Fr.) V. Wirth] - on soil, on psammophilous grasslands and heathlands; 5, 10, 11, 14, 17, 21, 26, 28.

30. Cladonia foliacea (Huds.) Willd. - on soil, on psammophilous grasslands; 1, 2, 4, 5, 10-12, 14, 26, 29.

31. Cladonia furcata (Huds.) Schrad. subsp. furcata - on soil, on psammophilous grasslands and heathlands; 1 , 2, 5, 6, 11, 12, 14, 17, 19-21, 26, 29, 30, 32.

32. Cladonia glauca Flörke - on soil, on psammophilous grasslands and heathlands; 4, 28.

33. Cladonia gracilis (L.) Willd. - on soil, on psammophilous grasslands and heathlands; 1, 2, 4-6, 10, 11, 12, 14, 17, 19, 20, 21, 26, 29.

34. Cladonia macilenta Hoffm. - on soil, on psammophilous grasslands and heathlands; 1,2, 3, 4, 5, 6, 8, 10, 11, 14, 16, 19, 20, 26, 27, 28, 29.

35. Cladonia phyllophora Hoffm. - on soil, on psammophilous grasslands and heathlands; 1-5, 10, 11, 13, 14, $16,17,19,21,26-29$.

36. Cladonia pleurota (Flörke) Schaer. - on soil, on heathlands; 4-6, 10, 11, 14, 17, 19, 21, 26, 29.

37. Cladonia portentosa (Dufour) Coem. - on soil, on heathlands; 1, 2, 5, 6, 15, 17, 19, 26, 27, 29.

38. Cladonia cf. pyxidata subsp. pocillum (Ach.) Schaer.on soil; 4

39. Cladonia rangiferina (L.) F. H. Wigg. - on soil, on psammophilous grasslands; 3, 11 .

40. Cladonia rangiformis Hoffm. - on soil, on heathlands; $24,26,30$.

41. Cladonia squamosa Hoffm. - on soil, on psammophilous grasslands and heathlands; 1, 6, 17, 28, 29.

42. Cladonia subulata (L.) F. H. Wigg. - on soil, on psammophilous grasslands and heathlands; 1, 2, 4-6, 11, 13, $14,26,30$.

43. Cladonia uncialis (L.) F. H. Wigg. - on soil, psammophilous grasslands; 1-6, 8, 10-12, 14-17, 19-21, 25, 26, 28-30, 32.

44. *Clypeococcum hypocenomycis D. Hawksw. - on tallus Hypocenomyce scalaris; 29, 30, 31.

45. Coenogonium pineti (Schrad. ex Ach.) Lücking \& Lumbsch - Ps; 4, 9, 29.
46. Diploschistes muscorum (Scop.) R. Sant. - on soil and Cladonia sp. squamules; 11, 19, 30, 33.

47. Evernia prunastri (L.) Ach. - Bp, Po, Qr, Sa; 4, 11, 29, 30, 31.

48. Flavoplaca citrina (Hoffm.) Arup, Frödén \& Søchting [Caloplaca citrina (Hoffm.) Th. Fr.] - on concrete; 2, 7, 10, 12, 16.

49. Flavoplaca flavocitrina (Nyl.) Arup, Frödén \& Søchting [Caloplaca flavocitrina (Nyl.) A.E.Wade] - on concrete; 7,12 .

50. Hypocenomyce scalaris (Ach.) M. Choisy - Bp, Ps, Po, Qr; 4, 8, 9, 20, 29-31.

51. Hypogymnia physodes (L.) Nyl. - Bp, Cv, Ps, Qr, on wood, on heathlands; 1-6, 8-12, 14-17, 19-21, 25, 26, 28-32.

52. Hypogymnia tubulosa (Schaer.) Hav. - on wood; 30.

53. Lecania cyrtella (Ach.) Th. Fr. - Pt; 29, 31

54. Lecanora albescens (Hoffm.) Flörke - on concrete; 7, $10,12$.

55. Lecanora chlarotera Nyl. - Po; 31.

56. Lecanora conizaeoides Cromb. - Bp, Cv, Ps, Qr, Rp, on wood; 1-32.

57. Lecanora dispersa (Pers.) Sommerf. - on concrete; 10, 12.

58. Lecanora hagenii (Ach.) Ach. - Bp, Pt; 17, 29, 31.

59. Lecanora saxicola (Pollich) Ach. [L. muralis (Schreb.) Rabenh., Protoparmeliopsis muralis (Schreb.) M. Choisy] - on concrete; 2.

60. Lecidella stigmatea (Ach.) Hertel \& Leuckert - on concrete; 10,12 .

61. Lepraria sp. - Bp, Ps, Po, Qr; 4, 8, 9, 11, 16, 20, 29, $30,31$.

62. *Lichenoconium erodens M. S. Christ. \& D. Hawksw. - on Hypocenomyce scalaris tallus, Hypogymnia physodes and Lecanora conizaeoides apothecia; 4-6, 12, 14, 15, 20, 21, 25, 26, 32.

63. *Lichenoconium lecanorae (Jaap) D. Hawksw. - on Lecanora conizaeoides; 1, 2, 12, 14, 15

64. Parmelia sulcata Taylor - Bp, Fr, Po, Pt, Qr, So, on wood; 4, 11, 29, 30, 31.

65. Parmeliopsis ambigua (Wulfen) Nyl. - Bp; 11, 12, 29, $31,32$.

66. Peltigera canina (L.) Willd. - on soil; 10, 11, 14, 26.

67. Peltigera cf. polydactylon (Neck.) Hoffm. - on soil; 26.

68. Peltigera didactyla (With.) J. R. Laundon - on gravel; 11, 15, 16, 26, 28, 30.

69. Peltigera praetextata (Sommerf.) Zopf - on gravel; 26, 30.

70. Peltigera rufescens (Weiss) Humb. - on soil; 14, 15, 24, 26, 27, 30, 33.

71. Pertusaria amara (Ach.) Nyl. - Qr; 29.

72. Phaeophyscia nigricans (Flörke) Moberg - on concrete; $2,12$. 
73. Phaeophyscia orbicularis (Neck.) Moberg - on concrete; $2,7,10,12,16$.

74. Phaeophyscia sciastra (Ach.) Moberg - on concrete; 16.

75. Phlyctis argena (Spreng.) Flot. - Pt; 17, 29, 31.

76. Physcia adscendens H. Olivier - Fr, Po, Pt; 4, 11, 29, 30, 31.

77. Physcia caesia (Hoffm.) Fürnr. - on concrete; 2, 7, 10, $12,16$.

78. Physcia tenella (Scop.) DC. - Po; 31.

79. Physconia distorta (With.) J. R. Laundon - Po; 31 .

80. Physconia grisea (Lam.) Poelt - Po; 31.

81. Placynthiella icmalea (Ach.) Coppins \& P. James - Bp, Po, Ps, Pt, on soil and wood; 16, 20, 29, 30, 31.

82. Placynthiella uliginosa (Schrad.) Coppins \& P. James - on soil; 26, 30.

83. Platismatia glauca (L.) W.L. Culb. \& C. F. Culb. - Bp; 16, 20, 29.

84. Polycauliona candelaria (L.) Frödén, Arup \& Søchting [Xanthoria candelaria (L.) Th. Fr.] - Bp, Po, Pt; 4, 29, 31.

85. Polycauliona polycarpa (Hoffm.) Frödén, Arup \& Søchting [Xanthoria polycarpa (Hoffm.) Rieber] - Bp, Po, Pt; 4, 29, 30, 31.

86. Pseudevernia furfuracea (L.) Zopf - Bp, Po, on wood; 4, 20, 29, 30.

87. Ramalina farinacea (L.) Ach. - Po; 4, 20, 31.

88. Ramalina fraxinea (L.) Ach. - Fr, Po; 4, 31.

89. Rusavskia elegans (Link) S. Y. Kondr. \& Kärnefelt [Xanthoria elegans (Link) Th. Fr.] - on concrete; 2, 7, $10,12,16$.

90. Sarcogyne regularis Körb. - on concrete; 2, 7, 16.

91. Scoliciosporum chlorococcum (Stenh.) Vězda - Fr, Po, Pt, on wood; 4, 11, 29, 30, 31.

92. Stereocaulon condensatum Hoffm. - on soil, on psammophilous grasslands and heathlands; 26.

93. Trapeliopsis flexuosa (Fr.) Coppins \& P. James - on wood; 4, 16, 29, 30, 31.

94. Trapeliopsis granulosa (Hoffm.) Lumbsch - on soil, on psammophilous grasslands and heathlands; 2, 12, 14, 26, 27, 29, 30.

95. Tuckermanopsis chlorophylla (Willd.) Hale - Bp; 16, 29.

96. Tuckermanopsis sepincola (Ehrh.) Hale - Bp; 6.

97. Usnea hirta (L.) F. H. Wigg. - Bp, Po; 4, 29.

98. Verrucaria muralis Ach. - on concrete; 2, 7, 10, 12, 16.

99. Verrucaria nigrescens Pers. - on concrete; 2, 7, 12, 16.

100. Xanthoria parietina (L.) Th. Fr. - Bp, Po, Pt; 4, 29, 31.
Table 1. The lichen species of military area near Torun included in the red list of threatened lichens in Poland (Cieśliński et al., 2006)

\begin{tabular}{|l|l|c|}
\hline $\begin{array}{l}\text { Category } \\
\text { of threat }\end{array}$ & Species & $\begin{array}{c}\text { Number } \\
\text { of species }\end{array}$ \\
\hline CR & Bryoria subcana & 1 \\
\hline EN & $\begin{array}{l}\text { Physconia distorta, Ramalina fraxinea, } \\
\text { Tuckermanopsis sepincola }\end{array}$ & 3 \\
\hline VU & $\begin{array}{l}\text { Bryoria fuscescens, Cetraria islandica, } \\
\text { Peltigera canina, P. polydactylon, } \\
\text { P. praetextata, Ramalina farinacea, } \\
\text { Stereocaulon condensatum, } \\
\text { Tuckermanopsis chlorophylla, Usnea } \\
\text { hirta }\end{array}$ & 9 \\
\hline NT & $\begin{array}{l}\text { Evernia prunastri, Hypogymnia } \\
\text { tubulosa }\end{array}$ & 2 \\
\hline LC & Phaeophyscia sciastra & 1 \\
\hline
\end{tabular}

Explanations: CR - Critically Endangered; EN - Endangered; VU - Vulnerable; NT - Near Threatened; LC - Least Concern

Table 2. The list of protected species occurring in military area (Regulation of the Minister of the Environment of 2014).

\begin{tabular}{|l|l|c|}
\hline $\begin{array}{l}\text { Status of } \\
\text { protection }\end{array}$ & Species & $\begin{array}{c}\text { Number } \\
\text { of } \\
\text { species }\end{array}$ \\
\hline OS & $\begin{array}{l}\text { Bryoria subcana, Peltigera praetextata, } \\
\text { Ramalina fraxinea, Tuckermanopsis } \\
\text { sepincola }\end{array}$ & 4 \\
\hline OC & $\begin{array}{l}\text { Bryoria fuscescens, Cetraria } \\
\text { islandica, Cladonia arbuscula, C. } \\
\text { ciliata, C. portentosa, C. rangiferina, } \\
\text { Hypogymia tubulosa, Peltigera } \\
\text { canina, P. polydactylon, Ramalina } \\
\text { farinacea, Stereocaulon condensatum, } \\
\text { Tuckermanopsis chlorophylla, Usnea } \\
\text { hirta }\end{array}$ & 13 \\
\hline
\end{tabular}

Explanations: OS - strictly protected; $\mathrm{OC}$ - partially protected

\section{Conclusions}

As evidenced by the preliminary lichenological studies, the military training ground near Torun is an interesting area because of the lichens occurring there. Military operations conducted in this area contributed to the preservation of valuable habitats, including mainly heaths and grasslands. Active conservation is recommended to preserve the nature of this place, in particular the abundance of lichens. 
Further detailed lichenological studies on the training ground are advisable to obtain full data on the species composition and the distribution of lichens.

\section{Acknowledgements}

The authors would like to express their gratitude to Dr. Wanda Gugnacka-Fiedor and Dr. Ryszard Dorożyński for their help during the fieldwork. We are thankful to Reviewers for their favorable review.

\section{References}

Abromeit J., Jentzsch A. \& Vogel G., 1898, Flora von Ostund Westpreussen, 1 Hälfte, I-III Teil, In Kommission bei R. Friedländer und Sohn, Berlin.

Adamska E., 2010, Biota of lichens on the Zadroże Dune and its immediate surroundings. Ecological Questions, 12: 51-58.

Adamska E., 2013, Lichens of heathlands in the city of Torun and Wielka Nieszawka Commune, Abstracts and excursion guide, 23-28 June 2013. 13 ${ }^{\text {th }}$ European Heathland Workshop, North Western dune and lowland heaths - natural processes and management, Denmark: 85-86.

Adamska E., 2014, Biota porostów Torunia na tle warunków siedliskowych miasta [Lichen biota in Torun in relation to habitat conditions of the city], Wydawnictwo Naukowe Uniwersytetu Mikołaja Kopernika w Toruniu, Toruń.

Arup U., Søchting U. \& Frödén P., 2013, A new taxonomy of the family Teloschistaceae. Nord. J. Bot., 31: 16-83.

Burak S. \& Jankowski J., 1991, Zasoby środowiska przyrodniczego województwa toruńskiego, Ochr. Środ. 2.

Burak S., 2001, Ochrona przyrody [Nature conservation], [in:] A. Przystalski (ed.), Przyroda województwa kujawsko-pomorskiego, Kujawsko-Pomorski Urząd Wojewódzki, Wojewódzki Konserwator Przyrody [Nature of the Kujawy-Pomerania Province, The Provincial Office of Kujawy and Pomerania, the Provincial Nature Conservation Officer], Bydgoszcz: 115-132.

Ciaciura M., Przybył I. \& Bosiacka B., 2006, Porosty projektowanego rezerwatu krajobrazowego „Diabelskie Pustacie“ na Pojezierzu Szczecineckim [Lichens of „Diabelskie Pustacie“ projected landscape reserve in the Szczecinek Lakeland], Frag. Flor. Geobot., 13(1): 183-190.

Ceynowa-Giełdon M., Adamska E. \& Kamiński D., 2004, Porosty w dolinie dolnej Wisły i na obszarze przemysłowym Kujaw [Lichens in the Lower Vistula Valley and In the industrial area ofc the Kujawy region], [in:] E. Krasicka-Korczyńska, M. Korczyński (eds), Wycieczki geobotaniczne. Region kujawsko-pomorski [Geobotanical excursions. The Kujawy-Pomerania Region], Bydgoszcz-Toruń: 13-22.

Chojnacka J., Cyzman W., Nienartowicz A. \& Deptuła M., 2010a, Comparison of the heath communities from the class Nardo-Callunetea from the Torun Basin and other regions of Poland, Ecological Questions, 12: 127-144.

Chojnacka J., Cyzman W., Nienartowicz A. \& Deptuła M., $2010 \mathrm{~b}$,Variability of the structure and directions in the development of heaths and grasslands within the artillery range near the city of Torun, Ecological Questions, 12: 87-125.

Cieśliński S., Czyżewska K. \& Fabiszewski J., 2006, Red list of the lichens in Poland, [in:] Z. Mirek, K. Zarzycki, W. Wojewoda, Z. Szeląg (eds) Red list of plants and fungi in Poland Eds. W. Szafer Inst. of Botany, PAN, Kraków: 71-89.

Czyżewska K. \& Kukwa M., 2009, Lichenicolous fungi of Poland. A catalogue and key to species, [in:] Biodiversity of Poland 11. Z. Mirek (ed.), W. Szafer Institute of Botany of Polish Academy of Sciences, Kraków: $1-133$.

Diederich P., Ertz D., Stapper N., Sérusiaux E., Van den Broeck D., Van den Boom P. \& Ries C., 2015, The lichens and lichenicolous fungi of Belgium, Luxembourg and northern France, URL: http://www.lichenology.info [20.03.2015].

Dingová A. \& Pišút I., 2010, Tree overlooked Cladonia species in Slovakia, Thaiszia - J. Bot., Košice, 20: 71-76.

Dorożyński R., 2001, mscr., Ogólna charakterystyka fizycznogeograficzna obszaru badań - Nadleśnictwo Gniewkowo [General physical and geographical description of the study area - the Forest division of Gniewkowo], RDLP, Toruń.

Gilbert O., 2000, The lichens of disused world war 2 airfields, Lichenologist, 32(6): 585-600.

Gugnacka-Fiedor W. \& Adamska E., 2010, The preservation state of the flora and vegetation of the artillery range near the city of Torun, Ecological Questions, 12: 75-86.

Klimaszewski M., 1978, Geomorfologia [Geomorphology], PWN, Warszawa.

Kondracki J., 2001, Geografia regionalna Polski [Regional geography of Poland], Wyd. Naukowe PWN, Warszawa.

Krenz K., Henning M., Felinks B. \& Kausch E., 2013, Maintaining the favourable conservation status of European Dry Heaths on an active military training area - a case study from the SAC Colbitz-Letzlinger Heide, Abstracts and excursion guide, 23-28 June 2013, $13^{\text {th }}$ European Heathland Workshop, North Western dune and lowland heaths - natural processes and management, Denmark: 35-36. 
Krzewicka B., 2012, A revision of Verrucaria s.1. (Verrucariaceae) in Poland, Polish Bot. Stud., 27: 3-143.

Laundon J. R., 2010, Lecanora antiqua, a new saxicolous species from Great Britain, and the nomenclature and authorship of L. albescens, L. conferta and L. muralis, Lichenologist, 42(6): 631-636.

Motiejūnaite J., 1996, Mycological and lichenological investigations in the former Soviet military forestries. Lichens and allied fungi, Botanica Lithuanica, 2(4): 343-364.

Motiejūnaitė J., 2007, Lichenized, lichenicolous and allied fungi of Žemaitija National Park (Lithuania), Herzogia, 20: 179-188.

Mrózek W., 1958, Wydmy Kotliny Toruńsko-Bydgoskiej [Dunes of the Toruń-Bydgoszcz Valley], PWN, Warszawa.

Noryśkiewicz A., 2013, Historia roślinności i osadnictwa ziemi chełmińskiej w późnym holocenie. Studium palinologiczne [History of vegetation and settlement of Chelmno in late Holocene. Palynological study], Wydawnictwo Naukowe UMK, Torun.

Orange A., James P. W. \& White F. J., 2001, Microchemical methods for the identification of lichens, British Lichen Society, London: 1-101.

Piercey-Normore M. D., Ahti T. \& Goward T., 2010, Phylogenetic and haplotype analyses of four segregates within Cladonia arbuscula s.1., Botany, 88(4): 397-408.

Preuss H., 1912, Die pontischen Pflanzenbestände im Weichselgebiet [in:] H. Conwentz (ed.) Beiträge zur Naturdenkmalpflege 2, 4; Berlin: 350-540.

Regulation of Minister of Environment, 2014, Rozporządzenie Ministra Środowiska z dnia 9 października 2014 r. w sprawie ochrony gatunkowej grzybów, Dz. U. nr 0, poz. 1408.
Santesson R., Moberg R., Nordin A., Tønberg T. \& Vitikainen O., 2004, Lichen-forming and lichenicolous fungi of Fennoscandia. Museum of Evolution. Uppsala University.

Scholz J. B., 1896, Vegetationsverhältnisse des preussichen Weichselgeländes. Kommissions-Verlag von E. Lambeck, Thorn.

Smith C. W., Aptroot A., Coppins B. J., Fletcher A., Gilbert O. L., James P. W. \& Wolseley P. A., 2009, The lichens of Great Britain and Ireland, British Lichen Society, London

Śliwa L., 2007, A revision of the Lecanora dispersa complex in North America, Polish Bot. J., 52(1): 1-70.

Szafer W. \& Pawlowski B., 1972, Podstawy geobotanicznego podziału Polski, [in:] W. Szafer, K Zarzycki (eds) Szata roślinna Polski vol. II, PWN, Warszawa: 9-15.

Trampler T., Kliczkowska A., Dmyterko E., Sierpińska A. \& Matuszkiewicz W., 1990, Regionalizacja przyrodniczo-leśna na podstawach ekologiczno-fizjograficznych, PWRiL, Warszawa.

Wasilewski S., 2004, Zarys historii toruńskiego poligonu artyleryjskiego, Centrum Szkolenia Artylerii i Uzbrojenia im. Gen. J. Bema, [An outline history of the artillery range in the city of Torun, General J. Bem Artillery and Armaments Training Centre], Toruń.

Westberg M. \& Arup U., 2011, Candelaria pacifica sp. nov. (Ascomycota, Candelariales) and the identity of $C$. vulgaris, Biblioth. Lichenol., 106: 353-364.

Wilkoń-Michalska J., 1971, Szata roślinna Kujaw. Przewodnik florystyczny [Vegetation cover of the Kujawy region, Floristic guidebook], Toruńskie Tow. Naukowe, Torun. 